\title{
Determination of Lead in fish, water and sediment
}

\author{
Siji Thomas ${ }^{1}$, Abbas.J.Mohaideen ${ }^{2}$ \\ ${ }^{1}$ (Research Scholar, Department of Chemical Engineering \\ Sathyabama University, Chennai, India) \\ ${ }^{2}$ (Principal, Maamallan Institute of Technology, Chennai, India)
}

\begin{abstract}
The objective of the study is to determine the concentration of Lead in water, sediment and the marine species, Indo-Pacific king mackerel popularly known as Spotted Seer fish (Scomberomorus Guttus) collected near seashore of Bay of Bengal from 5 locations (Pulicat, Ennore, Marina, Mahabalipuram and Kalpakkam) in North Chennai in 4 different seasons (Summer, Monsoon, Post-Monsoon, and Winter). The concentrations of Lead in each sample were determined using AAS method. Maximum concentrations of Lead in fish samples collected from different locations were $0.563 \mathrm{mg} / \mathrm{kg}$ (Pulicat - Summer), $0.722 \mathrm{mg} / \mathrm{kg}$ (Ennore Summer), $0.616 \mathrm{mg} / \mathrm{kg}$ (Marina - Monsoon), $0.363 \mathrm{mg} / \mathrm{kg}$ (Mahabalipuram - Summer) and $0.673 \mathrm{mg} / \mathrm{kg}$ (Kalpakkam - Post-Monsoon). Maximum concentration of Lead in water samples collected from different locations were $0.016 \mathrm{mg} / \mathrm{l}$ (Pulicat-Summer), $0.015 \mathrm{mg} / \mathrm{l}$ (Ennore-Monsoon), $0.012 \mathrm{mg} / \mathrm{l}$ (Marina- Monsoon and winter), $0.014 \mathrm{mg} / \mathrm{l}$ (Mahabalipuram-Monsoon) and $0.016 \mathrm{mg} / \mathrm{l}$ (Kalpakkam-Monsoon). The maximum concentrations of Lead in sediments collected from different locations were $1.083 \mathrm{mg} / \mathrm{kg}$ (Pulicat-Postmonsoon), $1.481 \mathrm{mg} / \mathrm{kg}$ (Ennore-Monsoon), $0.848 \mathrm{mg} / \mathrm{kg}$ (Marina- Summer), $1.004 \mathrm{mg} / \mathrm{kg}$ (MahabalipuramSummer) and $0.904 \mathrm{mg} / \mathrm{kg}$ (Kalpakkam- Post-monsoon).
\end{abstract}

Keywords: Chennai, concentration, fish, Lead, sediment, water

\section{Introduction}

Lead is a highly strong poison and is toxic to many organs and tissues like heart, bones, kidneys, reproductive and nervous systems. Since lead causes harmful health effects even at lower levels, no threshold for lead exposure has been discovered. ${ }^{[1][2]}$ Organic lead is more toxic than the inorganic lead due to its lipid solubility and the symptoms of organic lead poisoning happen rapidly ${ }^{[3]}$ Lead poisoning may be acute (from intense exposure of short duration) or chronic (from repeat low-level exposure over a prolonged period) and the latter is much more common.

The symptoms of lead poisoning vary in human beings depending on the individual and duration of exposure. ${ }^{[4]}$ The symptoms are different in adults and children. In adults, the symptoms of acute lead poisoning are stomach pain, vomiting, diarrhea, constipation, muscle weakness, paresthesia, weight loss, hemolysis, etc. The symptoms of chronic poisoning of lead are loss of short-term memory, depression, nausea, numbness, problems with sleep, fatigue, headache, tooth decay, slurred speech, anaemia etc. Children are more at risk for lead poisoning because lead is absorbed at a faster rate in children than in adults which causes more physical harm. ${ }^{[5]}$ In Children lead poisoning interferes with the development of the nervous system causing permanent learning and behavioral disorders, lethargy, intellectual disability, kidney failure etc. ${ }^{[5][6]}$

The contaminated air, water, soil, food and consumer products are the main routes of exposure to lead. ${ }^{[4]}$ Lead was widely used in paints and toys in older days and that causes the largest threat in children. Lead can be found in drinking water in homes containing pipes that were connected with lead solder. In adults, occupational exposure is the common cause of lead poisoning. ${ }^{[7]}$ The sources of lead are the facilities that produce lead acid batteries, radiation shields, ammunition, certain surgical equipments, circuit boarders, jet engines, ceramic glazes, sheet lead, billets, solder, casting metals, lead smelters etc. Other industrial sources of lead are metal processing, plastic manufacturing, paint and pigment manufacturing, ore processing, combustion of solid waste, lead mining and incinerators. ${ }^{[8][9] 10]}$ The children living near the facilities that process lead are higher at risk for lead poisoning. ${ }^{[11]}$ Lead paint is also a main route of lead exposure in children. ${ }^{[12]}$

The broken-down lead paint, used engine oil, pesticides, contaminated landfills, nearby industries, residues from lead containing gasoline etc. may impart lead content in soil. ${ }^{[13]}$ The lead from the atmosphere or soil can ultimately reach the surface and ground water. ${ }^{[14]}$

Fish is a valuable food item and source of protein. The concentration of heavy metals in aquatic organisms is higher than that present in water due to the effect of bio concentration and bio accumulation and eventually threaten the health of human by sea food consumption. ${ }^{[15]}$ Also Fishes are widely used as bio indicators of marine pollution by metals. ${ }^{[16]}$ So determination of heavy metal concentration in fishes is very important as far as human health is concerned. The samples (Spotted Seer fish, water and sediments) were collected in the seasons Summer (March-May, 2012), Monsoon (June - August, 2012), Post-Monsoon (September - November, 2012) and Winter (December 2012 - February 2013) from Pulicat, Ennore, Marina, 
Mahabalipuram and Kalpakkam. The aim of the study was to determine the concentration of Lead in fish muscle, water and sediment and to analyze it with respect to the seasons and locations.

\section{Methodology}

A. Study Area

The study area consists of 5 different locations (Pulicat, Ennore, Marina, Mahabalipuram and Kalpakkam) along the coast of Bay of Bengal in North Tamilnadu.

Pulicat (Pazhaverkadu) is a historic seashore town in Thiruvallur District, of Tamil Nadu. It is about $60 \mathrm{~km}$ north of Chennai and $3 \mathrm{~km}$ from Elavur, on the barrier island of Sriharikota, which separates Pulicat Lake from the Bay of Bengal.

Ennore is a suburb in Chennai, India. Ennore is situated on a peninsula and is bounded by the Korttalaiyar River, Ennore creek and the Bay of Bengal. The creek separates Ennore from the Ennore Port. The Ennore Industrial Complex is located adjacent to Manali Industrial Complex. It includes wastes from petrochemical complex, thermal power plant, pharmaceuticals, chemicals, fertilizers; automotive manufacturing unit and a coal fired thermal electricity station-ETPS.Ennore creek carries high load of heavy metals [17][188][19].

Marina Beach is an urban beach in the city of Chennai, India, along the Bay of Bengal, part of the Indian Ocean. The beach runs from near Fort St. George in the north to Besant Nagar in the south, a distance of $13 \mathrm{~km}$, making it the longest urban beach in the country and the world's second longest. Mahabalipuram lies on the Coromandel Coast which faces the Bay of Bengal. It is around $60 \mathrm{~km}$ south from the city of Chennai. It is an ancient historic town and was a bustling seaport during the time of Periplus and Ptolemy.

Kalpakkam is a small town in Tamil Nadu, situated on the Coromandel Coast 70 kilometers south of Chennai Nuclear facilities. Madras Atomic Power Station is located at Kalpakkam. It is a comprehensive nuclear power production, fuel reprocessing, and waste treatment facility that includes plutonium fuel fabrication for fast breeder reactors (FBRs). It is also India's first fully indigenously constructed nuclear power station. It has two units of $220 \mathrm{MW}$ capacities each.

\section{B. Materials and Methods}

The spotted seer fish samples (minimum 10 number of samples), water and sediment were collected from all the 5 locations in 4 different seasons, Summer (March-May, 2012), Monsoon (June - August, 2012), Post-Monsoon (September - November, 2012) and Winter (December 2012 - February 2013) within 500 meters from the seashore. The physiochemical parameters like Temperature, $\mathrm{pH}$, Salinity and Dissolved oxygen were measured.

The fish samples were washed thoroughly with distilled water to remove the sediments and debris. The length and weight of each sample were measured. Then the edible parts were separated and frozen at $-20^{\circ}$ for the analysis. The fish samples were thawed, and then dried in a hot air oven at $60^{\circ} \mathrm{C}$. After removing the moisture content, the weight was taken again. $15 \mathrm{gm}$ of fish sample was taken and the ashing was done at $500^{\circ} \mathrm{C}$ for 16 hours. After cooling, $2 \mathrm{ml}$ of Nitric Acid $\left(\mathrm{HNO}_{3}\right)$ and $10 \mathrm{ml}$ of 1 molar Hydrochloric Acid (HCl) were added. After digestion, samples were filtered using Whatman filter paper No. 41, and the filtrate is made up to $25 \mathrm{ml}$ with distilled water. Lead concentration was determined by Atomic Absorption Spectrophotometer (AAS). $100 \mathrm{ml}$ water sample was taken in a beaker and $0.5 \mathrm{ml}$ Nitric Acid $\left(\mathrm{HNO}_{3}\right)$ and $5 \mathrm{ml}$ Hydrochloric Acid $(\mathrm{HCl})$ were added. Then it is kept in a hot plate for digestion. After digestion, it was made up to $10 \mathrm{ml}$. Lead concentration was determined by Atomic Absorption Spectrophotometer (AAS).

$2 \mathrm{gm}$ of dry sediment was taken in a digestion vessel; $10 \mathrm{ml}$ of 1:1 Nitric acid $\left(\mathrm{HNO}_{3}\right)$ was added and covered with watch glass. It was heated at $95 \pm 5$ degree $\mathrm{C}$ for 10-15 min without boiling. After cooling, $5 \mathrm{ml}$ concentrated $\mathrm{HNO}_{3}$ was added and refluxed for 30 minutes. The step was repeated until no brown fumes come. The solution was allowed to evaporate to nearly $5 \mathrm{ml}$ by heat without boiling. After the sample has cooled, $2 \mathrm{ml}$ of water and $30 \% \mathrm{H}_{2} \mathrm{O}_{2}$ were added. Heated until effervescence subsides and vessel was cooled. $30 \% \mathrm{H}_{2} \mathrm{O}_{2}$ was added in $1 \mathrm{ml}$ aliquots with warming until the effervescence is minimal. The sample was covered with a ribbed watch glass and continued until the volume has been reduced to $5 \mathrm{ml} .10 \mathrm{ml} \mathrm{HCL}$ was added and refluxed for 15 min at $95 \pm 5$ degree C. The digestate was filtered through Whatman filter paper No.41 and was collected in 100 $\mathrm{ml}$ standard flask. Concentration of Lead was determined by Atomic Absorption Spectrophotometer (AAS).

\section{A. Fish}

\section{Results And Discussions}

The concentrations of Lead in Spotted Seer fish caught from 5 different locations in 4 different seasons are given in table 1 and the graphical representation of the maximum concentration in Figure 1. Maximum concentrations of Lead in Pulicat $(0.563 \mathrm{mg} / \mathrm{kg})$, Ennore $(0.722 \mathrm{mg} / \mathrm{kg})$ and Mahabalipuram $(0.363 \mathrm{mg} / \mathrm{kg})$ were observed in Summer season. . Maximum concentration of Lead in Marina $(0.616 \mathrm{mg} / \mathrm{kg})$ and Kalpakkam $(0.673$ 
$\mathrm{mg} / \mathrm{kg}$ ) were observed in Monsoon and Post-Monsoon seasons respectively.

B. Water

The concentrations of Lead in water collected from 5 different locations in 4 different seasons are given in Table 2 and the graphical representation in Figure 2. Maximum concentration of Lead in Ennore $(0.015$ $\mathrm{mg} / \mathrm{l})$, Mahabalipuram $(0.014 \mathrm{mg} / \mathrm{l})$ and Kalpakkam $(0.016 \mathrm{mg} / \mathrm{l})$ were observed in Monsoon season. Maximum concentration of Lead in Marina $(0.012 \mathrm{mg} / \mathrm{l})$ was observed in Monsoon and winter seasons and that in Pulicat $(0.016 \mathrm{mg} / \mathrm{l})$ was observed in Summer season.

\section{Sediment}

The concentrations of Lead in sediments collected from 5 different locations in 4 seasons are given in Table 3 and the graphical representation in Figure 3. The maximum concentration of Lead in Pulicat (1.083 $\mathrm{mg} / \mathrm{kg}$ ) and Kalpakkam $(0.904 \mathrm{mg} / \mathrm{kg})$ were observed in Post-monsoon season. Maximum concentration of Lead in Marina $(0.848 \mathrm{mg} / \mathrm{kg})$ and Mahabalipuram $(1.004 \mathrm{mg} / \mathrm{kg})$ were observed in Summer season and that in Ennore $(1.481 \mathrm{mg} / \mathrm{kg})$, was observed in Monsoon season.

Table. I Minimum and maximum values of concentration of Lead in fish caught from different locations in different seasons $(\mathrm{mg} / \mathrm{kg})$

\begin{tabular}{|c|l|l|l|l|l|l|l|l|l|l|}
\hline \multirow{2}{*}{$\begin{array}{c}\text { Seasons/ } \\
\text { Locations }\end{array}$} & Pulicat & Ennore & \multicolumn{2}{l|}{ Marina } & \multicolumn{2}{l|}{ Mahabalipuram } & \multicolumn{2}{l|}{ Kalpakkam } \\
\cline { 2 - 22 } & Min & Max & Min & Max & Min & Max & Min & Max & Min & Max \\
\hline Summer & BDL & 0.563 & 0.08 & 0.722 & BDL & 0.423 & BDL & 0.363 & BDL & 0.518 \\
\hline Monsoon & BDL & 0.521 & BDL & 0.716 & BDL & 0.616 & BDL & 0.318 & BDL & 0.486 \\
\hline Post-Monsoon & BDL & 0.368 & BDL & 0.375 & BDL & 0.203 & BDL & 0.286 & 0.071 & 0.673 \\
\hline Winter & BDL & 0.224 & BDL & 0.524 & BDL & 0.418 & BDL & 0.291 & BDL & 0.487 \\
\hline
\end{tabular}

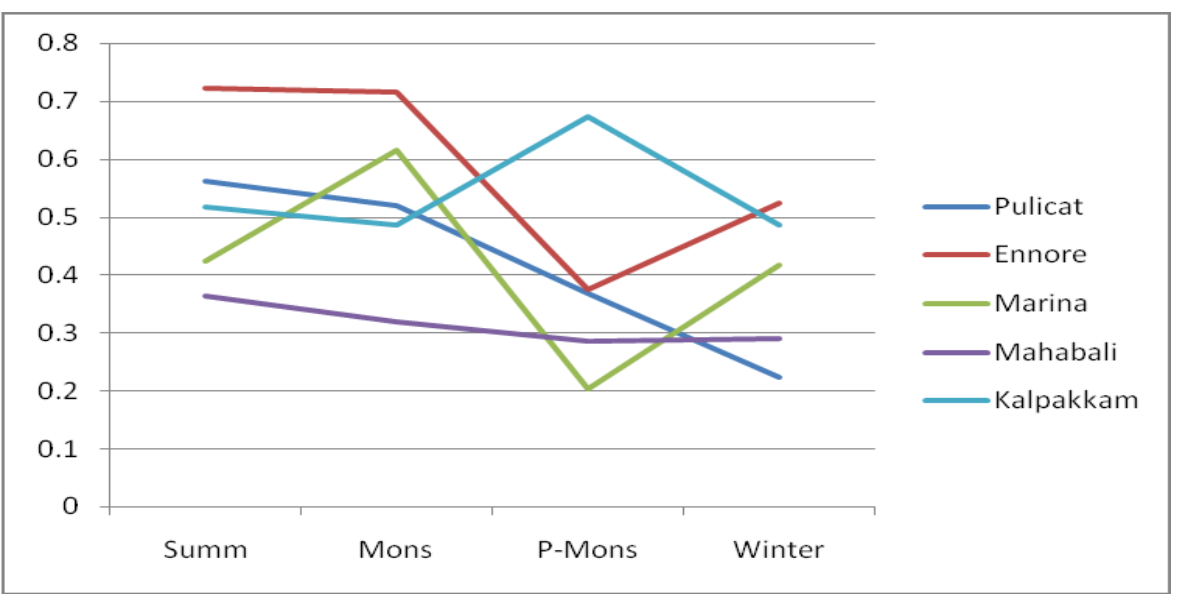

Figure1. Maximum Concentration of Lead in fish caught from different locations in different seasons $(\mathrm{mg} / \mathrm{kg})$

Table II. Concentration of Lead in water collected from different locations in different seasons (mg/l)

\begin{tabular}{|c|c|c|c|c|c|}
\hline Seasons/Locations & Pulicat & Ennore & Marina & Mahabalipuram & Kalpakkam \\
\hline Summer & 0.016 & 0.011 & 0.008 & 0.011 & 0.011 \\
\hline Monsoon & 0.014 & 0.015 & 0.012 & 0.014 & 0.016 \\
\hline Post-Monsoon & 0.015 & 0.014 & 0.006 & 0.012 & 0.013 \\
\hline Winter & 0.015 & 0.013 & 0.012 & 0.008 & 0.009 \\
\hline
\end{tabular}




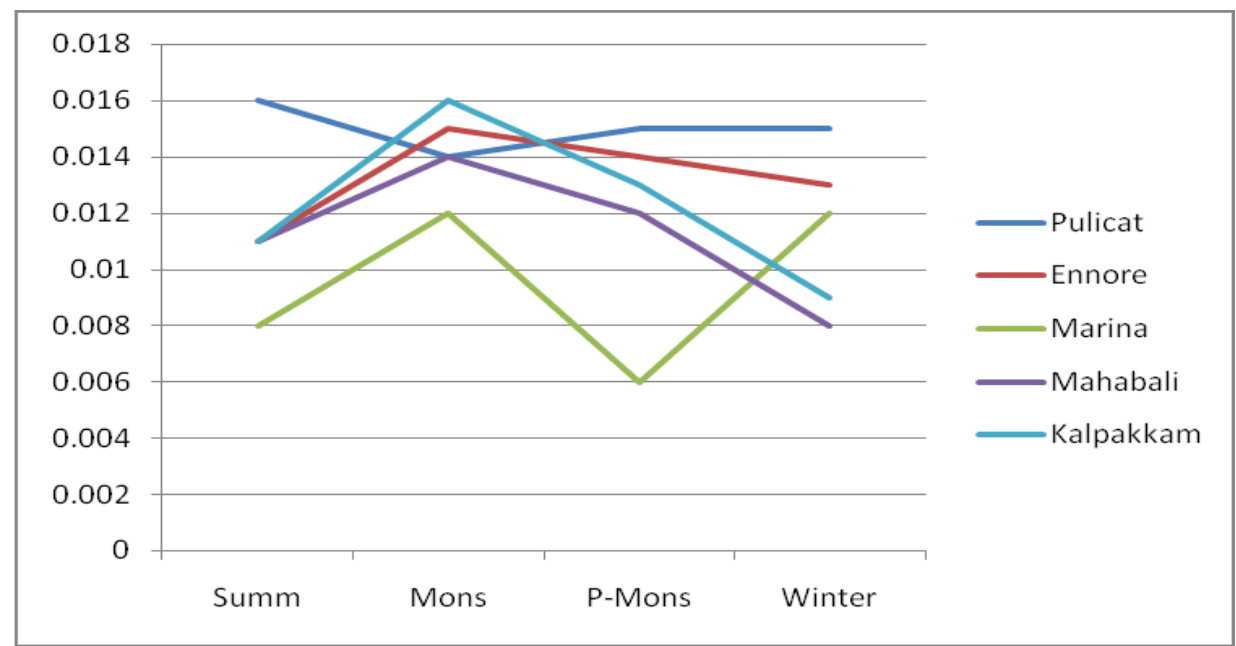

Figure 2. Concentration of Lead in water collected from different locations in different seasons (mg/l)

Table III. Concentration of Lead in sediment collected from different locations in different seasons $(\mathrm{mg} / \mathrm{kg}$ )

\begin{tabular}{|c|c|c|c|c|c|}
\hline Seasons/Locations & Pulicat & Ennore & Marina & Mahabalipuram & Kalpakkam \\
\hline Summer & 0.673 & 1.034 & 0.848 & 1.004 & 0.536 \\
\hline Monsoon & 0.468 & 1.481 & 0.363 & 0.412 & 0.241 \\
\hline Post-Monsoon & 1.083 & 1.273 & 0.574 & 0.952 & 0.904 \\
\hline Winter & 0.761 & 1.123 & 0.824 & 0.714 & 0.768 \\
\hline
\end{tabular}

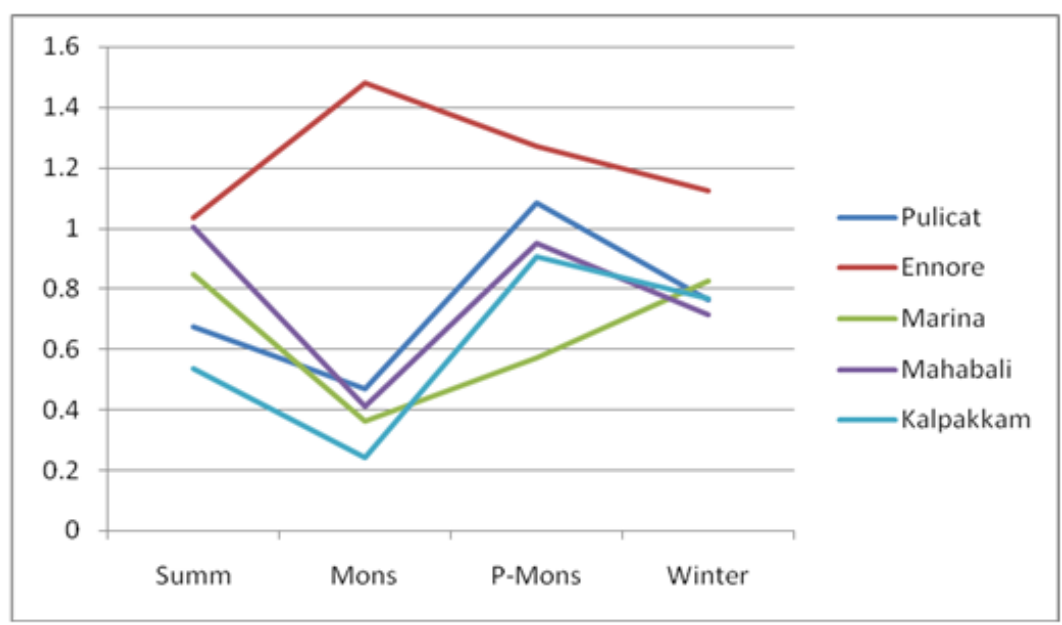

Figure 3. Concentration of Lead in sediment collected from different locations in different seasons $(\mathrm{mg} / \mathrm{kg})$

\section{Conclusion}

It is observed from this study that the highest Lead concentrations in fish caught during three seasons (Summer, Monsoon and Winter) were observed in Ennore. The maximum Lead concentration in water collected during summer, post-monsoon and winter seasons were observed in Pulicat. Highest concentrations in sediment collected during all the four seasons were also observed in Ennore. This shows the higher concentration of Lead in the effluents discharged from various industries located near Ennore. The domestic sewage and industrial effluents should be disposed safely after proper treatment, so as to avoid the contaminants to enter in to the environment. Also, laws to protect the environment should be enforced properly.

\section{References}

[1]. Enrico Rossi (2008) Low Level Environmental Lead Exposure - A Continuing Challenge. Clinical Biochemist reviews. The Australian Association of Clinical Biochemists 29 (2): Pages: 63-70

[2]. Fernando Barbosa, Jr, José Eduardo Tanus-Santos, [...], and Patrick J. Parsons (2005). A Critical Review of Biomarkers Used for Monitoring Human Exposure to Lead: Advantages, Limitations, and Future Needs. Environmental Health perspective, National Institute of Environmental Health Science.113(12). Pages:1669-74

[3]. John.A.Timbrell(2008) Biochemical mechanisms of toxicity,Specific examples.Principles of Biochemical toxicology $\left(4^{\text {th }}\right.$ Edition $)$ Informa Health care.

[4]. Surya K. Karri, Robert B. Saper, and Stefanos N. Kales, Lead Encephalopathy Due to Traditional Medicines, Current Drug Safety, JANUARY, 2008, 3(1)P:54-59 
[5]. Landrigan.PJ, Schechter.CB, Lipton JM, Fahs.MC, Schwartz.J (2002) "Environmental Pollutants and disease in American children: estimates of morbidity, maroality, and costs for lead poisoning, asthma, cancer, and developmental disabilities" Environmental health perspectives 110(7) Pages: 721-8

[6]. Pearce JM.( 2007) Burton's line in lead poisoning. European Neurology; 57: 118-1199

[7]. Needleman, H (2004). "Lead poisoning". Annual review of medicine 55: Pages: 209-22

[8]. Mañay, N; Cousillas, AZ; Alvarez, C; Heller, T (2008). "Lead contamination in Uruguay: the "La Teja" neighborhood case". Reviews of environmental contamination and toxicology. 195: Pages: 93-115

[9]. Patrick, L (2006). "Lead toxicity, a review of the literature. Part 1: Exposure, evaluation, and treatment". Alternative medicine review : a journal of clinical therapeutic 11 (1): Pages: 2-22

[10]. R.C. Dart, K.M. Hurlbut, L.V. Boyer-Hassen, "Lead". In Dart, RC. Medical Toxicology, Lippincott Williams \& Wilkins, 2004, 3rd edition

[11]. Sanborn MD, Abelsohn A, Campbell M, Weir E. (2002) Identifying and managing adverse environmental health effects:3, Lead exposure. Canadian Medical Association Journal. 166(10) Pages: 1287-1292.

[12]. Steven G. Gilbert and Bernard Weiss (2006) A rationale for lowering the blood lead action level from 10 to $2 \mu \mathrm{g} / \mathrm{dL}$ Neurotoxicology 27(5) Pages:693-701.

[13]. Woolf, AD; Goldman, R; Bellinger, DC (2007). "Update on the clinical management of childhood lead poisoning". Pediatric clinics of North America 54 (2): Pages: 271-94

[14]. Ming-Ho Yu (2005) Environmental toxicology ( $2^{\text {nd }}$ Edition) biological and health effects of pollutants Chapter 12 p.187

[15]. Ishaq S. Eneji, Rufus ShaíAto and P. A. Annune. Bioaccumulation of Heavy Metals in Fish (Tilapia Zilli and Clarias Gariepinus) Organs from River Benue, North ñ Central Nigeria Pak. J. Anal. Environ. Chem. Vol. 12, No. 1 \& 2 (2011) 25-31

[16]. Padmini, E. and Kavitha, M. 2005a. Contaminant induced stress impact on biochemical changes in brain of estuarine grey mullets. Poll. Res., 24: 647-651.

[17]. Jayaprakash,.M., Srinivasalu. S.Jonathan.M.P. and Mohan.V. 2005. A baseline study of physicochemical parameters and trace metals in water of Ennore Creek, Chennai, India. Mar. Poll. Bull., 50: 583-589.

[18]. E.Padmini and B.Vijaya Geetha, A comparative seasonal pollution assessment study on Ennore Estuary with respect to metal accumulation in the grey mullet, Mugil cephalus. Oceanological and Hydrobiological Studies. Volume 36, Issue 4, Pages 91-103.

[19]. Rajkumar, J.S.I., John Milton, M.C and Ambrose, T. Distribution of heavy metal concentrations in surface waters from Ennore Estuary, Tamil Nadu, India, International Journal of Current Research, Vol.3, Issue.3, Pages 237-244, March,2011 